\section{ECONOMICS}

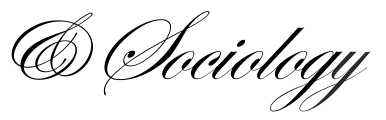

Enomoto, C. E., \& Douglas, K. (2019). Do Internet searches for Islamist propaganda precede or follow Islamist terrorist attacks?. Economics and Sociology, 12(1), 233-247. doi:10.14254/2071-789X.2019/12-1/13

\title{
DO INTERNET SEARCHES FOR ISLAMIST PROPAGANDA PRECEDE OR FOLLOW ISLAMIST TERRORIST ATTACKS?
}

\author{
Carl E. Enomoto, \\ New Mexico State University, Las \\ Cruces, NM, U.S.A, \\ E-mail: cenomoto@nmsu.edu
}

\author{
Kiana Douglas, \\ New Mexico State University, Las \\ Cruces, NM, U.S.A, \\ E-mail:kianaldouglas@gmail.com
}

\author{
Received: October, 2018 \\ 1st Revision: December, 2018 \\ Accepted: February, 2019
}

DOI: $10.14254 / 2071-$

789X.2019/12-1/13

JEL Classification: F52, F51,
C01

\begin{abstract}
Using a Vector-Autoregressive (VAR) model, this paper analyzes the relationship between Islamist terrorist attacks and Internet searches for the phrases such as "join Jihad" or "join ISIS." It was found that Internet searches for "join Jihad" and "taghut" (Arabic word meaning "to rebel") preceded the Islamist terrorist attacks by three weeks over the period January 2014 to December 2016. Internet searches for "kufar" (the derogatory Arabic word for non-Muslims) preceded the attacks that resulted in deaths from the Islamist terrorist groups. Casualties, including those injured and killed by the Islamist groups, were also found to precede Internet searches for "join Jihad" and "ISIS websites." Countermeasures to the usage of social media for terrorist activity are also discussed. As an example, if Internet searches for specific terms can be identified that precede a terrorist attack, authorities can be on alert to possibly stop an impending attack. Chat rooms and online discussion groups can also be used to disseminate information to argue against terrorist propaganda that is being released.
\end{abstract}

Keywords: Islamist terrorist attack, propaganda, Internet search, causality, VAR model.

\section{Introduction}

Islamist terrorist attacks are now becoming frequent, worldwide events. According to CNN (2018), "Since declaring its caliphate in June 2014, the self-proclaimed Islamic State has conducted or inspired more than 140 terrorist attacks in 29 countries other than Iraq and Syria, where its carnage has taken a much deadlier toll. Those attacks have killed at least 2,043 people and injured thousands more" (p.1). Some have attributed these attacks to social media and the radicalization that follows. The examples include the shooting at the Fort Lauderdale Airport in Florida on January 6, 2017. The shooter reportedly spoke with other "...jihadis in chatrooms and websites inspired by the Islamic State, the terrorist group also known as ISIS or ISIL" (Sheth, 2017). After the Orlando nightclub shooting on June 12, 2016, President Obama stated that there was no clear link between the shooter and ISIS, but the shooter may have been influenced by what he saw online (BBC News, 2016). On London's Westminster Bridge, an attacker drove into pedestrians and stabbed a policeman on March 22, 2017. Authorities were 
considering the possibility that his actions were due to what he saw online (Holden and Hosenball, 2017).

It may be, however, that it is not the searching for jihadist websites that leads to terrorist attacks, but it is the terrorist attacks that are leading to the Internet searches for jihadist websites. A portion of terrorist communication is not found on the regular world-wide-web where users can find it using search engines like Google, but rather it is found on the Dark Web (Weimann, 2016). According to Weimann, the Dark Web is only accessible using special browsers or special software. In this case, terrorist attacks are drawing in the attention of those individuals who have sympathy for the beliefs of the attackers (or are just curious) and are causing those individuals to search the Internet for Islamist propaganda. No radicalization or attacks may be taking place because of the searches for terrorist propaganda.

The purpose of this paper is to determine the direction of causality between the Internet searches for Islamist phrases such as "Join Jihad" or "Isis Websites," and the number of actual Islamist terrorist attacks worldwide. If the direction of causality is from the Internet searches for terrorist propaganda to terrorist attacks, that does provide authorities with useful information. However, there could be many external factors at play. For example, economic factors may be giving rise to the Internet searches for terrorist propaganda in the first place. Military conflicts in the states may have a correlation with terrorist attacks, independent of the Internet searches for propaganda. Global meetings, official speeches and resolutions also affect terrorist attacks, independent of or in conjunction with the Internet searches for terrorist propaganda.

The purpose of this paper is not to consider all the factors affecting terrorist attacks worldwide, but to focus on one aspect of terrorism specifically -- the timing between Internet searches for terrorist propaganda and terrorist attacks.

Conway (2017) stated,

It is impossible to adequately answer the question of why the Internet is playing a greater role in contemporary violent extremism and terrorism absent prior knowledge of what role, if any, the Internet is playing in the latter. Unfortunately, basic descriptive research is largely missing from this field, along with more complex theory-informed approaches seeking to show causal connections. This is pretty astounding given the treasure trove of data now available online.

Aaron Zelin observed as recently as 2013 that:

More than 11 years after the attacks of 9/11 and nearly a decade since the rise of popular online jihadi Internet forums, there is strikingly little empirical research on the manner in which jihadi activists use the Web to propagate their cause. Whereas researchers and policy analysts have systematically collected and analyzed the primary source material produced by al-Qaeda and its allies, very little work has been done on the conduits through which that information is distributed - and even to what extent, anyone is accessing that propaganda other than counterterrorism analysts (pp. 78-79).

The purpose of this paper is to fill this gap in the literature.

The outline of this paper is as follows. In the next section, a brief overview of the literature on Islamist terrorist groups and social media will be given. Section 2 discusses the data collected for this study followed by the model used to estimate the relationships between internet searches for Islamist propaganda and Islamist terrorist attacks throughout the world. The final section contains conclusions and a discussion of the findings. 


\section{Literature review}

\subsection{Islamist Groups}

According to the Constitutional Rights Foundation (2018), Islamist groups have different goals but many common beliefs.

Although their goals may differ, Islamist groups generally want to set up states based on Islamic fundamentalism, or literal interpretation of the Koran, the holy scripture of Islam, and the Hadith, a collection of sayings of the Prophet Muhammad. They believe that government based on Sharia, or Islamic law, is superior to any government based on secular laws, democracy in which multiple political views are represented, or any religion other than fundamentalist Islam.

Many Islamist terrorists, often called jihadist terrorists, view themselves as following Muhammad's example. Muhammad in A.D. 622 had to flee from Mecca with a small band of followers. Yet in 630, he returned with an army of followers to conquer Mecca and then spread Islam throughout the Arabian Peninsula. Terrorist groups often see themselves as small bands that will similarly lead Islam to victory.

The overwhelming majority of Muslims deplore terrorist attacks and view them as violating the Koran. Most fundamentalist Muslims also believe terrorism violates Islamic law. Nonetheless, the Islamic State and other jihadist groups draw their supporters from the ranks of Islamic fundamentalists (p. 1).

There are several Jihadist groups (Islamist terrorist groups) throughout the world. Gardner (2014) lists the following. 1) Al-Qaeda in the Arabian Peninsula, 2) Islamic State in Iraq and the Levant (ISIS), 3) Al-Qaeda in the Islamic Maghreb, 4) Boko Haram, 5) Al-Shabab, 6) Taliban, 7) Ansal al-Sharia in Libya, 8) Ansar al-Sharia in Tunisia, 9) Jemaah Islamiah, 10) Abu Sayyaf, and 11) Ansar Bayt Al-Maqdis. Gardner stated that these groups have continued to flourish in many countries due to corrupt governments that abuse their power and people.

While many papers in the literature have discussed the beliefs and activities of Islamist terrorist groups, none of them that the authors are aware of, have statistically measured the direction of causality between internet searches for Islamist propaganda and Islamist terrorist attacks. If internet searches for specific terms are preceding terrorist attacks, countermeasures can be developed. These countermeasures may involve closely monitoring internet activity for specific searches, identifying individuals and organizations in the communication network, and ascertaining plans of these entities. If, on the other hand, Islamist terrorist attacks are leading to internet searches for Islamist propaganda but not vice versa, then internet searches for Islamist propaganda may have been done by curiosity seekers or others who may not intend to commit a terrorist attack.

\subsection{Social Media and Islamist Terrorism}

Twitter has been used by Islamist extremists to spread their propaganda and recruit future members to their cause. According to Ullah (2017, p.10), “...as of August 2017, the Sunni Islamist militia Jabhat al-Nusra had over 300,000 followers on affiliated sites, and @ikhwanweb, the Muslim Brotherhood's English-language account, had 145,000.” Furthermore, the extremists are constantly changing their twitter accounts to avoid being blocked by the regulators of Twitter. "One of the most notorious is the al-Shabaab press office's 
English-language Twitter account, originally set up in 2011, which continually posts extremist content, is continually blocked, and continually regenerates under slightly different names. During Al-Shabaab's attack on a Kenyan shopping mall in 2013, for instance, the group livetweeted the attack's progress despite Twitter's best efforts to stop them" (ibid, p. 11-12). Ullah provides further examples of how Islamist extremists have used social media such as Facebook and YouTube, to further their cause and recruit new members. Examples include showing videos where others had insulted the Prophet Muhammad and the burning of the Koran by a Christian pastor in the U.S.

Parekh, Amarasingam, Dawson and Ruths (2018) have proposed a new way of collecting data from social media like Twitter to track jihadist terrorist plans, operations and movements. By accounting for the relations and interactions of social media users, a "social graph" can be modeled which excludes irrelevant information.

Hassan (2018) has recognized that propaganda from the Islamic State continues to be put on the internet and authorities have a difficult time controlling it. The propaganda focuses on generating support against non-Muslim armies in Muslim territory. Hassan also highlights how the Islamic State tries to persuade youth to go against parental consent and join jihad. However, it is pointed out that extremist Islamist groups do not have the theological justification for doing this.

Soliev (2018) discussed the threats made by the Islamic State against the 2018 World Cup games in Russia, using online propaganda. This threat may have been brought on by Russian involvement in Syria and Iraq. Soliev traces the time line of propaganda against the World Cup by looking at specific events. "In October 2017, the pro-IS Wafa' Media Foundation released digitally altered images of football superstars like Neymar, Lionel Messi and Cristiano Ronaldo being executed in its propaganda materials. IS supporters and sympathizers in different parts of the world have subsequently joined the pro-IS online extremist group in their propaganda campaign (p. 17)." Soliev argues that the propaganda campaign by the Islamic State could bring about attacks from other sources as well.

In a recent U.S. Senate hearing, opinions were voiced on "Isis Online: Countering Terrorist Radicalization and Recruitment on the Internet and Social Media" (Committee on Homeland Security and Governmental Affairs, U.S. Senate, 2016). Senator Portman, in his opening comments, reported on how ISIS had used online propaganda as a weapon. "The damage wrought by that weapon is considerable: Orlando, 49 dead; San Bernardino, 14; Fort Hood, 13 dead; the Boston Marathon, 3 dead and hundreds wounded. Each of these killers was reportedly radicalized to some degree by online jihadist content (p. 2)." The subcommittee also noted that ISIS posts online instructions to those in English-speaking countries, on how to make their trip to Syria (p. 71).

Charlie Winter (2016) stated that most Islamist propaganda is in Arabic, however, "there are official propaganda channels operating in no less than nine languages..." (p. 9). The propaganda discusses life in the caliphate, paints a picture of abundance and friendship, and presents an alternative lifestyle which attracts recruits. The final step in the recruitment process involves an enlister. "This is the point at which the process usually enters encrypted communications and becomes clandestine (p. 11)." Von Behr, Reding, Edwards, and Gribbon (2013) analyzed how the internet was used in the radicalization of terrorists in the U.K. They reported that a Google search for "how to make a bomb" gave 1,830,000 results. A search for "Salafi publications" gave 46,200 results and a search for "beheading video" gave 257,000 results (p. 3). The authors concluded that the internet increased the opportunity and speed of radicalization, based on interviews with radicalized individuals.

Bertram and Ellison (2014) reported that 112 websites were found that were associated with Sub Saharan African terrorist groups (p. 9). Most of the terrorist web activity took place in the Eastern, Western and Southern regions of Africa. 
Veilleux-Lepage (2016) discussed the evolution of Islamist propaganda in moving Muslims to jihad. Starting with amateur videos from 2004 to 2007 and the first "authentic jihadist website," azzam.com, extremists soon moved into YouTube (p. 37). The author stated, "Aided by the popularity of such mediums and the fact that no Arabic language skills or high level of Internet literacy were now required to locate jihadist content, YouTube rapidly became a significant platform for jihadist groups and their supporters, fostering a thriving subculture which used it to communicate and share propaganda worldwide" (p. 39). Twitter accounts and e-Magazines have also been used by terrorist groups.

Thompson (2011) described why social media like Facebook, Twitter, and YouTube, are well suited to meet the needs of radicals. By uploading videos or sending out a tweet, one individual can influence many. Radicalization and recruitment are more easily accomplished from those countries with access to the internet.

Conway (2006) examined how terrorists use the internet. These uses include, (1) information provision and publicity, (2) financing through the sale of books and videos, (3) exploitation of e-commerce tools and entities such as credit card fraud and the use of internet businesses to fund terrorist activities, (4) networking to allow greater communication between different terrorist groups, (5) recruitment, (6) data mining to gather sensitive information about other nations, and (7) sharing information such as how to make bombs.

Conway (2012) gave several examples of how the internet had been used by those in favor of violent jihad to spread their message and plan and carry out attacks. Online radicalization could have played a role in the cases of the London bombers in 2005, the shooting of two U.S. airmen in the Frankfurt Airport in 2010, the Fort Hood shootings in 2009, and others (p. 1). Furthermore, the internet and social media have made the messages of the violent jihadist more readily available to those who do not speak Arabic as these messages are now translated into many languages.

Weimann (2004) analyzed how terrorist groups use the internet. He found that the websites of terrorists contained information about the group, their political beliefs, their accomplishments, leaders, and goals. The terrorist groups also wanted to spread disinformation and fear and gain publicity for themselves. They also want to use their websites to justify the violence they use against enemies.

The Homeland Security Institute (2009) outlined how the internet was being used by terrorists to attract young people to their organizations. By using games, cartoons, videos and special designs on their websites, terrorist groups can introduce themselves to young people whom they would not otherwise reach. Younger people are also more likely to be in close communication with their peers, and thus terrorist messages are more easily transmitted to a larger audience.

The United Nations Office on Drugs and Crime (2012) reported on the use of the internet by terrorist groups. Some of the reasons these groups used the internet were to promote their propaganda, promote violence, radicalize groups of young people, recruit new members, finance their organizations, and plan an attack. Ways the internet could be used to counter terrorist activity were also given.

A paper by Beckmann, Dewenter, and Thomas (2017) and another paper by Pfeiffer (2012) looked at the relationship between news media coverage and terrorist attacks. Using Granger Causality tests, they found a bidirectional relationship between news articles on terrorism and terrorist attacks.

In the next section, the data used in this study to examine the relationship between internet searches for Islamist propaganda and Islamist terrorist attacks will be described. 


\section{Methodological approach}

Weekly worldwide data from 2014 to 2016 was collected from the website, "The Religion of Peace," for the number of Islamist terrorist attacks, the number of casualties from such attacks (killed and injured), and the number killed from such attacks. Table 1 provides descriptive statistics for these variables.

Table 1. Descriptive Statistics of Variables

\begin{tabular}{lcc} 
Variable & Mean & std. dev. \\
\hline number of attacks & 53.86 & 10.91 \\
total number of casualties & $1,036.15$ & 515.14 \\
killed & 522.97 & 391.1
\end{tabular}

Number of weekly internet searches for phrases such as "Join Jihad," "Join ISIS," "ISIS chat rooms," "ISIS recruitment", "ISIS websites," "ISIS twitter," "khilafa," (successor (Fernandez, 2015)), "jizya," (poll tax to humiliate Christians and Jews (ibid)), "taghut," (jihadist term for "others" associated with idolatry and unbelief (ibid)), and "kufar," (which refers to infidels and is a term used for the jihadist movement (ibid)), were taken from Google Trends. Furthermore, “taqiyya" (concealing one's true identity or denying one's religion (1389 Blog-Counterjihad, 2013)), was translated into its Arabic representation and a measure of weekly internet searches for this term was found using Arabic Google Trends.

According to Fernandez (2015), "There certainly is a jihadist ideology that must be defeated, beyond crushing ISIS on the battlefield in Syria and Iraq, but in the volatile world of social media, what often marks jihadism is not so much an ideology fully formed and understood but a semi-digested revolutionary argot of highly symbolic words and phrases jihadist shorthand mostly divorced from history and context, dumbed down for the zealous convert, and used as an ideological blunt instrument" (p. 1). Fernandez stated that "khilafa," for example, was revived by ISIS to remind people of the caliphate. "Jizya," was revised by ISIS to let Christians and Jews know that if they don't convert, they will be subject to discrimination and taxes. "Taghut," has a complicated history, according to Fernandez, but can refer to the overthrow of anti-jihadist regimes. "Taqiyya," comes from the Quran which states, "Let believers not make friends with infidels in preference to the faithful...," according to 1389 Blog-Counterjihad (2013).

The different phrases described above were put into Google Trends which gives search volume indexes over time for the different phrases. As an example, if a search is done for "ISIS websites," and the geographical area selected for searches in the world, then the search volume index (SVI) will be a number between 0 and 100 for different weeks in a year. The SVI for a week is calculated by taking the number of worldwide searches for the phrase "ISIS websites" and dividing by the total number of worldwide Google searches. This proportion is then normalized by the week with the highest proportion. As an example, suppose for the first week of May 2017, Google searches for the phrase "ISIS websites" as a proportion of all searches was 0.30 , and on the first week of September 2016, the proportion was 0.90. Also, suppose that the week with the highest proportion of searches was the first week of September 2016. All weekly proportions are then normalized to 0.90 . Thus, the search volume index for the phrase "ISIS websites," for the first week of May 2017 would be $0.30 / 0.90$ which would be 0.33 or 33 after multiplying by 100 . A higher search volume index for a given week shows greater interest in a particular phrase relative to a week with a lower SVI.

Google Trends search volume indices have been used by many researchers. Ricketts and Silva (2017) used Google Trends to analyze morbidity and mortality based on specific Google 
search terms. Vicens-Feliberty and Ricketts (2016) used Google Trends to analyze how Google searches in Puerto Rico for terms involving "moving to the U.S.," affected actual migration. Enomoto, Noor, and Widner (2017) used Google Trends to see how searches for different dating sites and apps such as Tinder, Zoosk, and Eharmony, were related to cases of STDs in different U.S. states. Other papers that have used Google Trends include Choi and Varian (2012), Vosen and Schmidt (2011), and Wu and Brynjolfsson (2013).

All variables and number of searches for the various terms and phrases (as measured by Google Trends search volume indices) used in this study were collected each week from January 2014 to December 2016 which resulted in 156 observations. Furthermore, all variables and number of searches for the different phrases were found to be stationary using the Augmented Dickey-Fuller test.

In the next section, the Vector Autoregressive (VAR) model used in this study is described and the results are presented.

\section{Conducting research and results}

VAR models (vector-autoregressive models) have been used by many researchers to determine the direction of causality between variables such as advertising and sales, monetary policy and interest rates, economic development and political democracy, and many other variables. The advantage of using VAR models is that once the optimal lag structure for the variables is found using different statistics such as the AIC (Akaike information criterion) or SC (Schwarz information criterion) or other established statistics, Granger causality tests can be applied to see which variable affects the others. In this study, a two-equation, two-variable VAR (vector autoregressive) model was estimated such as the one below, to determine if internet searches for Islamist propaganda preceded or followed Islamist terrorist attacks.

$$
\begin{gathered}
Y_{t}=\beta_{0}+\beta_{1} Y_{t-1}+\ldots+\beta_{k} Y_{t-k}+\alpha_{1} X_{t-1}+\ldots+\alpha_{k} X_{t-k}+u_{t} \\
X_{t}=\delta_{0}+\delta_{1} Y_{t-1}+\ldots+\delta_{k} Y_{t-k}+\gamma_{1} X_{t-1}+\ldots+\gamma_{k} X_{t-k}+v_{t} .
\end{gathered}
$$

In equations (1) and (2), the variable $Y_{t}$ represents a weekly measure of Islamist terrorist activity. Such measures include (a) number of Islamist terrorist attacks worldwide, (b) a total number of casualties from Islamist terrorist attacks worldwide including number killed and the number injured, and (c) total number killed from Islamist terrorist attacks worldwide. The variable $X_{t}$ represents weekly worldwide internet searches for Islamist propaganda as measured by Google Trends search volume indices. Examples of $X_{t}$ include search phrases such as "join jihad," "Isis websites," and "taghut" which is jihadist shorthand for "the other," for idolatry and unbelief” (Fernadez, 2015).

In the VAR model, there are two hypotheses of interest: $H_{0}^{1}: \alpha_{1}=\alpha_{2}=\ldots=0$ and $H_{0}^{2}: \delta_{2}=\delta_{3}=\ldots=0$. One of four conclusions can be reached: (a) We fail to reject $H_{0}^{1}$ and $H_{0}^{2}$ , in which case there is no Granger causality between $\mathrm{X}$ and Y. (b) We fail to reject $H_{0}^{1}$ but reject $H_{0}^{2}$, in which case $\mathrm{Y}$ is said to Granger-cause $\mathrm{X}$. (c) We reject $H_{0}^{1}$ but fail to reject, in which case $\mathrm{X}$ is said to Granger-cause $\mathrm{Y}$. (d) We reject $H_{0}^{1}$ and $H_{0}^{2}$, in which case there is bidirectional causality between $\mathrm{X}$ and $\mathrm{Y}$. 


\subsection{Application of multiple linear regression analysis}

In the first model that was estimated, $Y_{t}$ was the weekly worldwide number of Islamist terrorist attacks. The variable $X_{t}$ was a measure of the weekly worldwide number of internet searches for the phrase "join jihad." As previously discussed, the Google trends search volume index for "join jihad" was used for this measure. To determine the lag length used in the VAR model represented by equations (1) and (2), five statistics were examined: (1) the LR sequential modified LR test statistic, (2) the FPE (the final prediction error statistic), (3) the AIC (Akaike information criterion), (4) the SC (Schwarz information criterion), and (5) the HQ (HannanQuinn information criterion). The lag length that was identified as the best from the majority of the five statistics was used. In this case, that lag length was three weeks. Furthermore, all of the inverse roots of the characteristic polynomial were within the unit circle indicating a stable VAR model. Tests for autocorrelation (Portmanteau autocorrelation test) and heteroscedasticity (White's heteroscedasticity test using levels and squares of the regressors) indicated no autocorrelation or heteroscedasticity present. The results of the Granger causality test are given below in Table 2.

Table 2. VAR Granger Causality Tests Between Number of Islamist Terrorist Attacks and Internet Searches for "Join Jihad."

\section{Dependent Variable: Number of Islamist Terrorist Attacks}

$\frac{\text { Variable }}{\text { Join Jihad }} \quad \frac{\text { Chi-square }}{9.718^{*}} \quad \frac{\text { DF }}{3} \quad \frac{\text { Prob }}{0.0211}$

Dependent Variable: "Join Jihad"

\begin{tabular}{|c|c|c|c|}
\hline Variable & Chi-square & DF & Prob \\
\hline$\overline{\text { Number of Islami }}$ & & & \\
\hline Terrorist Attacks & 1.8 & 3 & 0.6149 \\
\hline
\end{tabular}

*Indicates significance at the $5 \%$ level

In this case, internet searches for "Join Jihad" are preceding Islamist terrorist attacks by three weeks, given the significant chi-square statistic of 9.718. However, the number of Islamist terrorist attacks is not leading to internet searches for "Join Jihad," given the insignificant chisquare statistic of 1.8. These results are reinforced when examining the estimates of equations (1) and (2) of the VAR model.

$$
Y_{t}=\underset{(2.68)^{*}}{10.99}+\underset{(3.30)}{0.26} Y_{t-1}+\underset{(2.75)}{0.22} Y_{t-2}+\underset{(3.07)}{0.24} Y_{t-3}-\underset{(-0.50)}{0.03} X_{t-1}+\underset{(0.71)}{0.04} X_{t-2}+\underset{(2.33)}{0.12} X_{t-3}
$$

$\mathrm{R}$-squared $=0.45, \mathrm{AIC}=7.12, \mathrm{n}=153, * \mathrm{t}$-statistics in parentheses

$$
X_{t}=\underset{(1.16)^{*}}{7.20}+\underset{(1.30)}{0.16} Y_{t-1}-\underset{(-0.65)}{0.08} Y_{t-2}-\underset{(-0.51)}{0.06} Y_{t-3}+\underset{(4.93)}{0.40} X_{t-1}+\underset{(2.16)}{0.18} X_{t-2}+\underset{(1.67)}{0.14} X_{t-3}
$$

R-squared $=0.39, \mathrm{AIC}=7.95, \mathrm{n}=153, * \mathrm{t}$-statistics in parentheses 
With $Y=$ number of attacks and $X=$ internet searches for "Join Jihad," equation (1a) and the results from Table 2, show that the past values of $X$ jointly affect the current value of $Y$ after controlling for past values of $Y$. More specifically, the coefficient $X_{t-3}$ is positive and significant indicating that internet searches for the term "Join Jihad" three weeks ago had a positive effect on the current number of Islamist terrorist attacks worldwide. Equation (2a) and the results from Table 2, on the other hand, show no individual effects or group effects of past terrorist attacks (Y) on current internet searches for "Join Jihad" (X).

In the above model, $Y_{t}$ was used to represent the weekly worldwide number of Islamist terrorist attacks. It may be, however, that other measures of Islamist terrorist activity either lead to internet searches for Islamist propaganda or are led by internet searches. In a second model, $Y_{t}$ was defined to be a weekly worldwide number of casualties (killed and injured) from Islamist terrorism. Thus, it may be that it is the actual number killed and injured from Islamist terrorism, rather than simply the number of incidents or Islamist terrorist attacks, that affects or is affected by internet searches for the phrase "join Jihad." Equations (1) and (2) above were again estimated with $Y_{t}$ taking on this new definition. The best lag length was determined to be two weeks. The VAR model was also identified as stable with no autocorrelation or heteroscedasticity detected. The results of the Granger causality test are given in Table 3.

Table 3. VAR Granger Causality Tests Between Number of Casualties from Islamist Terrorist Attacks and Internet Searches for "Join Jihad."

Dependent Variable: Number of Casualties from Islamist Terrorist Attacks

$\frac{\text { Variable }}{\text { Join Jihad }} \quad \frac{\text { Chi-square }}{3.855} \quad \frac{\text { DF }}{2} \quad \frac{\text { Prob }}{0.1455}$

Dependent Variable: "Join Jihad"

\begin{tabular}{|c|c|c|c|}
\hline Variable & Chi-square & DF & Prob \\
\hline Number of Casualties from & & & \\
\hline Islamist Terrorist Attacks & $7.223^{*}$ & 2 & 0.027 \\
\hline
\end{tabular}

*Indicates significance at the $5 \%$ level

The results from Table 3 indicate that searches for the phrase "join Jihad," did not precede or Granger cause number of casualties from Islamist terrorist attacks. However, a number of casualties did precede or Granger causes internet searches for "join Jihad." While the number of Islamist terrorist attacks per week did not give rise to internet searches for "join Jihad" from the previous model, a number of casualties has had a greater impact on individuals and their internet search behavior. This may in part, be due to the news coverage is given these types of events. If terrorist attacks are unsuccessful for the terrorists and no one is injured or killed, there may be little news coverage. If there are casualties, there is more news coverage and more internet searches for Islamist propaganda.

The results from Table 3 are reinforced by looking at the estimates of equations (1) and (2) when $Y_{t}$ is a number of weekly-worldwide casualties. These estimates are presented in equations (1b) and (2b). 


$$
Y_{t}=\underset{(5.92)^{*}}{0.82}+\underset{(1.61)}{0.13} Y_{t-1}-\underset{(-0.35)}{0.03} Y_{t-2}-\underset{(-0.63)}{2.01} X_{t-1}+\underset{(1.90)}{5.96} X_{t-2}
$$

$\mathrm{R}$-squared $=0.04, \mathrm{AIC}=7.12, \mathrm{n}=154, * \mathrm{t}$-statistics in parentheses

$$
X_{t}=\underset{(1.15)^{*}}{3.87}+\underset{(2.65)}{0.01} Y_{t-1}+\underset{(0.16)}{0.0003} Y_{t-2}+\underset{(5.11)}{0.40} X_{t-1}+\underset{(3.43)}{0.26} X_{t-2}
$$

R-squared $=0.39, \mathrm{AIC}=7.92, \mathrm{n}=154, *$ t-statistics in parentheses

In equations ( $1 \mathrm{~b})$ and $(2 \mathrm{~b}), Y_{t}$ is a number of weekly worldwide casualties from Islamist terrorist attacks and $X_{t}$ is number of weekly internet searches for "join Jihad," which is measured using the Google Trends search volume index. The results support the Granger causality tests from Table 3 , showing that in equation (1b), internet searches are not preceding a number of casualties. However, equation (2b) shows that the number of casualties per week is preceding or Granger causing internet searches for "join Jihad." More specifically, equation (2b) indicates that number or casualties in a week have a significant and positive effect on a number of internet searches for "join Jihad" in the following week.

Equations (1) and (2) were re-estimated to consider the internet search phrase "ISIS websites," In this case, $Y_{t}$ was a weekly worldwide number of casualties from Islamist terrorist attacks and $X_{t}$ was a weekly number of internet searches for "ISIS websites." The lag length was determined to be one week given the LR, FPE, AIC, SC, and HQ statistics. The VAR model was stable with no autocorrelation or heteroscedasticity detected. Granger causality tests indicated that casualties from Islamist terrorist attacks preceded internet searches for "ISIS websites," by one week. No Granger causality was found when looking at a number of internet searches for "ISIS websites" and number of Islamist terrorist attacks.

Another VAR model was estimated to consider internet searches for "Taghut," which refers to disbelievers or people who worship a god other than Allah. In equations (1) and (2), $Y_{t}$ was a number of weekly worldwide attacks by Islamist terrorist groups and $X_{t}$ was weekly worldwide- internet searches for the term "Taghut." The best lag length was determined to be three weeks, and the VAR model was stable with no indication of autocorrelation or heteroscedasticity. The Granger causality tests are given in Table 4.

Table 4. VAR Granger Causality Tests Between Number of Islamist Terrorist Attacks and Internet Searches for "Taghut".

Dependent Variable: Number of Islamist Terrorist Attacks

$\frac{\text { Variable }}{\text { Taghut }} \quad \frac{\text { Chi-square }}{8.564^{*}} \quad \frac{\text { DF }}{3} \quad \frac{\text { Prob }}{0.036}$

Dependent Variable: "Taghut"

\begin{tabular}{lccc} 
Variable & Chi-square & DF & Prob \\
\cline { 2 - 3 } $\begin{array}{l}\text { Number of Attacks from } \\
\text { Islamist Terrorist Groups }\end{array}$ & 3.075 & 3 & 0.38 \\
\hline
\end{tabular}

*Indicates significance at the 5\% level 
The results in Table 4 show that internet searches for "Taghut" preceded or Granger caused a number of Islamist terrorist attacks, but attacks did not Granger cause internet searches for "Taghut." The internet searches may be an indication of the discontent, frustration, resentment, and anger that extremist groups are feeling towards those they feel are infidels.

The results of Table 4 are consistent with the estimates of equations (1) and (2) of the VAR model given below.

$$
Y_{t}=\underset{(2.84)^{*}}{14.18}+\underset{(4.45)}{0.36} Y_{t-1}+\underset{(2.25)}{0.19} Y_{t-2}+\underset{(2.82)}{0.22} Y_{t-3}-\underset{(-2.26)}{0.11} X_{t-1}+\underset{(2.10)}{0.11 X_{t-2}}-\underset{(-0.97)}{0.05} X_{t-3}
$$

$\mathrm{R}$-squared $=0.45, \mathrm{AIC}=7.12, \mathrm{n}=153, * \mathrm{t}$-statistics in parentheses

$$
X_{t}=\underset{(3.47)^{*}}{27.97}+\underset{(0.03)}{0.08} Y_{t-1}-\underset{(-1.00)}{0.13} Y_{t-2}-\underset{(-0.88)}{0.11 Y_{t-3}}+\underset{(2.17)}{0.18} X_{t-1}+\underset{(1.42)}{0.12} X_{t-2}+\underset{(2.14)}{0.18} X_{t-3}
$$

$\mathrm{R}$-squared $=0.44, \mathrm{AIC}=8.08, \mathrm{n}=153, * \mathrm{t}$-statistics in parentheses

In equations (1c) and (2c), $Y_{t}$ was a number of attacks and $X_{t}$ was number of internet searches for "Taghut." In equation (1c), the coefficients of $X_{t-1}$ and $X_{t-2}$ were the same but opposite in sign. Increases in internet searches for "Taghut" are leading to more attacks in two weeks while decreases in internet searches for "Taghut" are leading to more attacks in one week. It may be that once the internet searches are made two weeks before an attack, the time for radical propaganda is over and the time for preparing for an attack has come. No Granger causality was found between internet searches for "Taghut" and number of casualties.

Similar results to those in Table 4 were found when using the internet search term "kufar," which refers to infidels and the jihadist movement. Internet searches for "kufar" preceded the number killed in Islamist terrorist attacks, while the number killed in Islamist terrorist attacks did not Granger cause internet searches for "kufar." No Granger causality was found between internet searches for "kufar" and number of casualties, or between internet searches for "kufar" and number of attacks.

The above results are summarized in Table 5. In Table 5, in the row for "join Jihad," a "yes" appears under the heading "Number of Attacks/week" and under the subheading "Searches $\rightarrow$ Attacks." This means that the number of internet searches for the term "join Jihad" preceded or Granger caused a number of radical Islamic terrorist attacks. A "no" under the subheading "Attacks $\rightarrow$ Searches," means that a number of Islamist terrorist attacks did not precede or Granger cause internet searches for "join Jihad." The results in Table 5 indicate that internet searches for "taghut" also preceded or Granger caused a number of Islamist terrorist attacks and number of internet searches for "kufar" preceded or Granger caused the number killed in Islamist terrorist attacks. Furthermore, the number of casualties from Islamist terrorist attacks, preceded or Granger caused a number of internet searches for "join Jihad" and "ISIS websites."

\begin{tabular}{|c|c|c|c|c|}
\hline Internet & Number of Attacks/week & & Number of Casualties/week & \\
\hline Search term & Searches $\rightarrow$ Attacks & Attacks $\rightarrow$ Searches & Searches $\rightarrow$ Casualties & Casualties $\rightarrow$ Searches \\
\hline join Jihad & yes & no & no & yes \\
\hline ISIS websites & no & no & no & yes \\
\hline taghut & yes & no & no & no \\
\hline kufar & no & no & yes* & no \\
\hline
\end{tabular}

Table 5. Summary of Granger Causality Tests

*indicates that internet search preceded number killed rather than number of casualties (number killed and injured) 
The remaining Google search phrases: "join ISIS," "ISIS chatrooms," "ISIS recruitment," "ISIS twitter," "khlifa," "jizya," and "taqiyya" (in its Arabic form), were found to not affect or be affected by number of terrorist attacks or number of casualties from Islamist terrorist attacks. Finally, as a test for the validity of the VAR model used in this paper, two random search phrases: "sandwich" and "keys," were used to see if they affected or were affected by a number of Islamist terrorist attacks and number of casualties from Islamist terrorist attacks. It was found that there was no Granger causality between either "sandwich" or "keys" and the number of attacks or number of causalities. Furthermore, using the search term "peace", there was no Granger causality between "peace" and number of attacks or total number of casualties. There was also no Granger causality between searches for "harmony" and number of attacks or total number of casualties. There was no Granger causality between the search term "love" and total number of attacks. Searches for the term "love" did not Granger cause casualties. However, at the $6 \%$ level of significance, number of casualties did Granger cause internet searches for the term "love." Perhaps the world is reaching out and in sympathy for those hurt by terrorism.

\section{Conclusion}

Much of the existing literature on social media and terrorism focuses on how terrorist groups are using Facebook, Twitter, YouTube, chat rooms, and websites, to spread their propaganda and recruit new members. What has not been explored is how internet searches for specific phrases such as "join Jihad," "ISIS chat rooms, "taghut," "kufar," or others, have affected or are affected by Islamist terrorist attacks. This paper addresses these issues. It was found that 1) internet searches for "join Jihad," preceded Islamist terrorist attacks by three weeks. 2) Casualties from Islamist terrorist attacks preceded internet searches for "join Jihad" and "ISIS websites." 3) Internet searches for "taghut" preceded Islamist terrorist attacks by one week and two weeks. 4) Internet searches for "kufar" preceded the number killed by Islamist terrorist attacks. These results indicate that internet searches for certain phrases are related to Islamist terrorist attacks.

One possible explanation for the lag length is that there are two groups of individuals: those not yet radicalized and those already radicalized. Approximately three weeks before the attack some eternal political/social condition results in (a) leading those not yet radicalized to become more interested and start searching on the topic while simultaneous (b) encouraging those already radicalized to begin planning an attack for 3 weeks out. This second alreadyradicalized group may also be further encouraged to plan an attack because of the increased search volume, increased contacts from potential recruits and increased support in the online community. Thus, those creating high search volume are not necessarily the same people as those who will conduct the attack, but either or both groups are influenced by outside conditions and the searching group may be encouraging the attacking group. These steps linking internet searches for Islamist propaganda and terrorist attacks are outlined in Figure 1.

The United Nations Office on Drugs and Crime (UNODC, 2012) came up with several strategies for countering the use of the internet for terrorist activities. As an example, internet activity used by terrorists can be monitored, and information can be gathered by the authorities to identify and possibly stop terrorist attacks. Chat rooms and online discussion groups can be used to provide opposing opinions to those of the terrorists. If more facts are presented, radicalization may not take place. Furthermore, the internet can be used to identify those individuals specifically involved in recruiting. Finally, the internet can be closely monitored for spikes in specific search phrases. Appropriate action can then be taken when possible. 


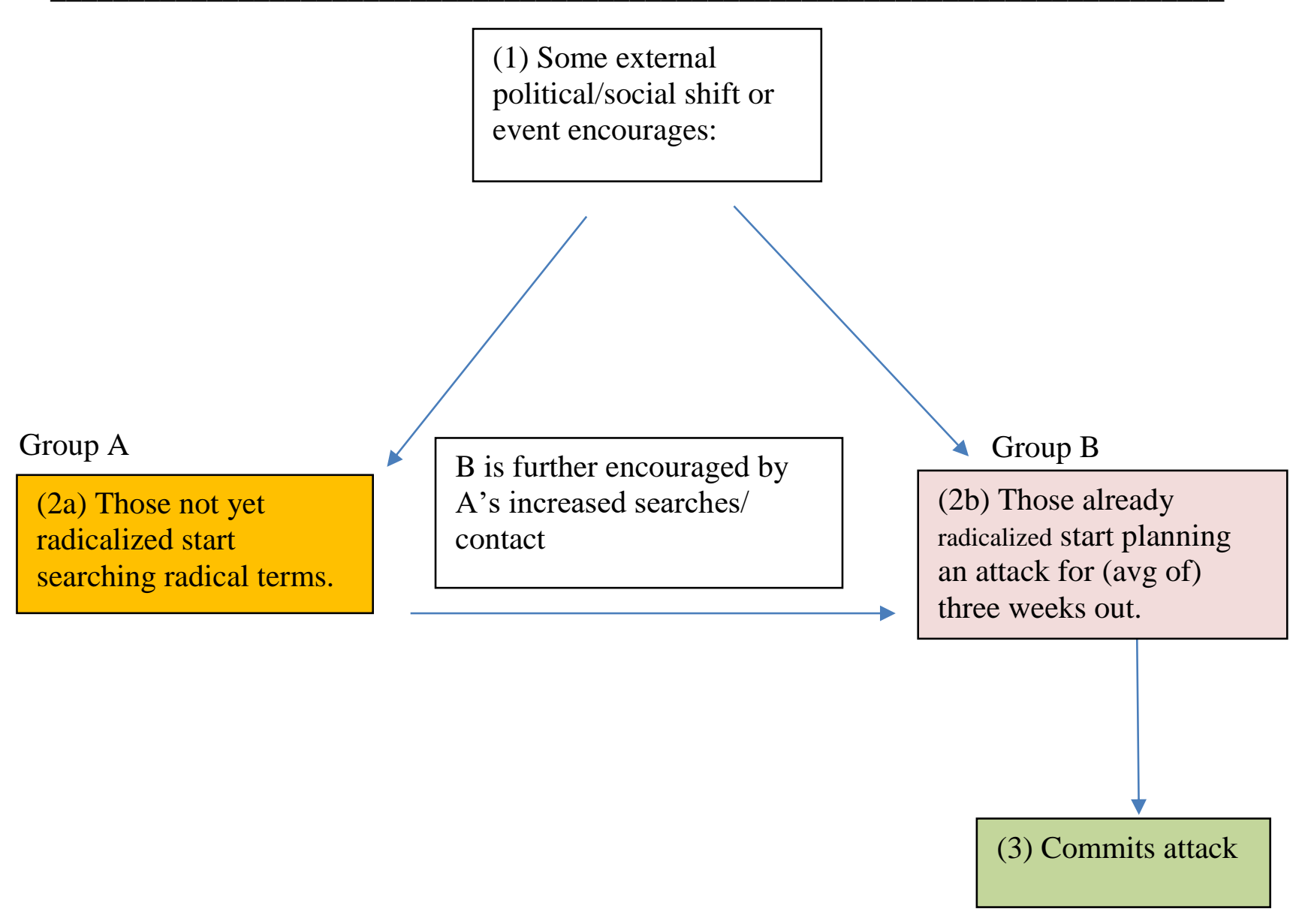

Figure 1. From internet searches for Islamist propaganda to an attack

There are several directions for future researchers to take when studying the relationship between social media and terrorism. First, it was noted in the literature review that the terrorists are using multiple languages on websites in disseminating their propaganda. In future studies, Google search volume indices may be collected for searches performed in various languages. Second, the reasons for those engaging in online searches for terrorist propaganda need to be studied. What are individuals looking for from these websites? Do these individuals see abuses and injustices that must be addressed? Third, Google Trends provides a number of internet searches for specific phrases for different regions, not just worldwide searches. Thus future studies may be able to find out which regions are responsible for the majority of internet searches for certain phrases. Answers to these questions may help establish a better understanding of the link between radicalization and terrorism and ways to break it.

\section{References}

BBC News (2016). Orlando nightclub shooting: How the attack unfolded, Retrieved on February 16, 2018, from http://www.bbc.com/news/world-us-canada-36511778.

Beckmann, K. B., Dewenter, R., \& Thomas, T. (2017). Can news draw blood? The impact of media coverage on the number and severity of terror attacks. Peace Economics, Peace Science and Public Policy, 23(1).1-16. 
Behr, I.V., Reding, A., Edwards, C., \& Gribbon, L. (2013). Radicalisation in the digital era: The use of the internet in 15 cases of terrorism and extremism. RAND Europe.

Bertram, S. \& Ellison, K. (2014). Sub-Saharan African terrorist group's use of the internet. Journal of Terrorism Research, 5(1), 5-26.

Choi, H. \& Varian, H. (2012) Predicting the present with google trends. Economic Record, $88(\mathrm{~S} 1): 2-9$.

CNN (2018) ISIS goes global: 143 attacks in 29 countries have killed 2,043. Retrieved on January 10, 2019, from https://www.cnn.com/2015/12/17/world/mapping-isis-attacksaround-the-world/index.html.

Committee on Homeland Security and Governmental Affairs United States Senate (2016). ISIS online: Countering terrorist radicalization and recruitment on the internet and social media. U.S. Government Publishing Office. Washington, D.C.

Constitutional Rights Foundation (2018). Islamist terrorism from 1945 to the rise of ISIS. Retrieved on February 16, 2018, from http://www.crf-usa.org/america-responds-toterrorism/islamist-terrorism-from-1945-to--the-death-of-osama-bin-laden.html.

Conway, M. (2017). Determining the role of the internet in violent extremism and terrorism: Six suggestions for progressing research. Studies in Conflict \& Terrorism, 40(1), 77-98.

Conway, M. (2006). Terrorism and the internet: New media - new threat? Parliamentary Affairs, 59(2), 283-298.

Conway, M. (2012). From al-Zarqawi to al-Awlaki: The emergence of the internet as a new Form of violent radical milieu, Retrieved on February 16, 2018, from http://www.isodarco.it/courses/andalo12/doc/Zarqawi\%20to\%20Awlaki_V2.pdf.

Enomoto, C., Noor, S. \& Widner, B. (2017). Is social media to blame for the sharp rise in stds? Social Sciences, 6(3), 78.

Fernandez, A.M. (2015). Islamic words that kill. MEMRI: The Middle East Media Research Institute. Retrieved on January 11, 2019, from https://www.memri.org/reports/islamicwords-kill.

Gardner, F. (2014). Jihadist groups around the world. BBC News. Retrieved on February 16, 2018 from: http://www.bbc.com/news/world-middle-east-27930414.

Hassan, M. H. (2018). Refuting Islamic State (IS) jihad propaganda with the story of Uwais AlQarni. Counter Terrorist Trends and Analyses, 10(10), 12-16.

Holden, M., \& Hosenball, M. (2017). Investigators suspect UK killer was lone wolf radicalized on internet. Retrieved on January 11, 2019 from: https://www.reuters.com/article/usbritain-security-masood/investigators-suspect-uk-killer-was-lone-wolf-radicalized-oninternet-idUSKBN171242.

Homeland Security Institute (2009). The internet as a terrorist tool for recruitment and radicalisation of youth, Retrieved on February 16, 2018 from: http://barakaconsult.com/uploads/reports\%20on\%20internet_radicalization.pdf.

Parekh, D.; Amarasingam, A.; Dawson, L. \& D. Ruths (2018). Studying jihadists on social media: A critique of data collection methodologies. Perspectives on Terrorism, 12(3), 321.

Pfeifer, C. (2012). Causalities and casualties: Media attention and terrorism, 1970-2010, Diskussionspapier, Helmut-Schmidt-Universität, Fächergruppe Volkswirtschaftslehre127.

Ricketts, C.F. \& C.G. Silva (2017). An analysis of morbidity and mortality using Google trends. Journal of Human Behavior in Social Environment, 27(6), 1-12.

Sheth, S. (2017). FBI: Fort Lauderdale shooting suspect says he carried out the attack on behalf of ISIS. Retrieved on January 22, 2018, from http://www.businessinsider.com/fbi-fortlauderdale-shooting-suspect-says-he-carried-out-the-attack-on-behalf-of-isis-2017-1.

Soliev, Nodirbek. (2018). Terrorist threat to the 2018 world cup in Russia. Counter Terrorist Trends and Analyses, 10(6), 16-21. 
The Religion of Peace (Website), Retrieved on February 8, 2018, from: https://www.thereligionofpeace.com/attacks/attacks.aspx?Yr=2017.

Thompson, R. (2011). Radicalization and the Use of Social Media'. Journal of Strategic Security, 4(4), 167-190.

Ullah, H.K. (2017). Digital world war: Islamists, extremists, and the fight for cyber supremacy. Yale University Press. New Haven and London.

United Nations Office on Drugs and Crime (UNODC) (2012). The use of the Internet for terrorist purposes. Retrieved on January 18, 2018 from: http://www.unodc.org/documents/frontpage/Use_of_Internet_for_Terrorist_Purposes.pdf.

Vicens-Feliberty, M.A., \& Ricketts, C.F. (2016). An analysis of Puerto Rican interest to migrate to the United States using Google Trends. The Journal of Developing Areas, 50(2), 411430.

Veilleux-Lepage, Y. (2016). Paradigmatic shifts in jihadism in cyberspace: The emerging role of unaffiliated sympathizers in Islamic State's social media strategy. Journal of Terrorism Research, 7(1), 36-51.

Vosen, S., \& Schmidt, T. (2011). Forecasting private consumption: Survey-based indicators vs. Google Trends. Journal of Forecasting, 30(6), 565-578.

Weimann, G. (2004). www.terror.net: How Modern Terrorism Uses the Internet. United States Institute of Peace. Retrieved on January 18, 2018, from: https://www.usip.org/sites/default/files/sr116.pdf.

Winter, C. (2016). Special report: An integrated approach to Islamic State recruitment. Australian Strategic Policy Institute: Counter-Terrorism Policy Centre.

Wu, L., \& Brynjolfsson, E. (2013). The future of prediction: How Google searches foreshadow housing prices and sales. Available from: Economics of Digitization, University of Chicago Press.

Zelin, A. (2013). The State of Global Jihad Online: A Qualitative, Quantitative, and Cross Lingual Analysis. New America Foundation. Washington, D.C.

1389 Blog-Counterjihad (2013). Four Arabic words every infidel must know. Retrieved on January 25, 2018 from: http://1389blog.com/2013/06/23/four-arabic-words-every-infidelmust-know/. 